\title{
PENINGKATAN EKONOMI MASYARAKAT MELALUI OLAHAN KREATIF DAN BRANDING
}

\author{
Stefanus Rumangkit \\ Jurusan Manajemen, Fakultas Ekonomi dan Bisnis \\ Insitut Informatika dan Bisnis Darmajaya, Jl. Z.A. Pagar Alam No.93 Bandar Lampung \\ email: kit240187@gmail.com
}

\begin{abstract}
Abstrak
Permasalahan yang terjadi di Kampung Liman Benawi adalah rendahnya pengetahuan, kemampuan, serta keahlian dalam membuat olahan produk kreatif. Selain itu, permasalah yang lain adalah tingkah kesejahteraan masyarakat, terutama petani terong tergolong masih rendah. Tujuan kegiatan pengabdian kepada masyarakat ini adalah untuk meningkatkan pendapatan ekonomi para petani teror dengan melakukan transfer knowledge, berupa pembuatan produk kreatif dari hasil panen mereka, yaitu: manisan terong dan keripik terong. Metode yang digunakan dalam kegiatan pengabdian masyarakat, dengan metode pelatihan. Pertama, yang dilakukan adalah mendemonstrasikan pembuatan produk manisan terong dan keripik terong. Kedua, membuat logo atau merek dagang. Ketiga, melakukan penjulan dan distribusi produk. Hasil dari kegiatan pengabdian, adalah diterimanya produk olahan kreatif petani terong oleh masyarkat luas. Hal ini berdampak pada peningkatan ekonomi petani tersebut.
\end{abstract}

Kata Kunci : Produk Kreatif, Branding, Liman Benawi, Lampung, Hasil Olahan, Terong

\section{PENDAHULUAN}

Kampung Liman Benawi yang berlokasi di Kecamatan Trimurjo, Kabupaten Trimurjo memiliki luas Kampung sebesar 423,17 Km. Kondisi Geografis Kampung Liman Benawi berada pada ketinggian 265 meter di atas permukaan air laut, sedangkan secara orbitasi adalah: a) Jarak dari Pemerintahan Kecamatan yaitu $3 \mathrm{Km}, \mathrm{b}$ ) Jarak dari Ibu Kota Kabupaten yaitu $38 \mathrm{Km}$, c) Jarak dari Ibu Kota Provinsi yaitu $43 \mathrm{Km}$, d) Jarak dari Ibu Kota Negara yaitu 145 Km. Kondisi Penduduk Kampung Liman Benawi terbagi menjadi 6 Dusun. Dengan mayoritas penduduknya berusia 16-55 tahun \& sebagian besar berprofesi sebagai Petani. Kampung Liman Benawi ini terdapat sarana \& pra-sarana, meliputi: Sarana Beribadah, Sarana Pendidikan, Sarana Sosial dan Seni Budaya, Sarana Perekonomian, Sarana Pertanian,
Sarana Keamanan dan Kesehatan, Sarana Perhubungan dan Transportasi.

Masyarakat di Kampung Liman Benawi bermata pencaharian bervariasi, meliputi: petani Semangka dan terong, peternak unggas, pembuat meubel dan penambang batu. Akan tetapi permasalahan yang dihadapi oleh masyarkat tersebut adalah minimnya pengetahuan untuk membuat sesuatu yang inovatif, sehingga memiliki nilai ekonomis yang jauh lebih tinggi. Oleh karena itu, kegiatan pengabdian ini akan membantu masyarakat di Kampung Liman Benawi untuk membuat suatu produk yang kreatif dan inovatif sehingga membawa dampak peningkatan ekonomi bagi masyarakat, khususnya petani terong.

Para petani terong yang ada di Kampung Liman Benawi, menjual hasil panenya hanya dengan mendistribusikan ke kota, pasar-pasar, dan warung-warung disekitar wilayah. Sehingga, pendapatan yang didapat 
oleh petani tersebut tidak sesuai dengan harapan. Oleh karena itu, untuk meningkatkan pendapatan masyarakat, maka akan dilakukan transfer knowlegde, untuk menciptakan suatu hasil olahan yang memiliki keterbaharuan, dengan berbahan dasar terong.

Hasil observasi serta wawancara dengan kepala kampung dan petani terong, masalah yang menjadi kendala, yaitu: petani minim dalam melakukan inovasi, terutama dalam pemanfaatan limbah hasil produksi. Sehingga limbah yang ada masih dibuang begitu saja. Tanpa adanya upaya untuk mengelola ulang limbah hasil produksi tersebut, Oleh karena itu, kegiatan ini akan memberikan solusi untuk menangani kesulitan atau kendala-kendala yang dihadapi oleh petani terong di Kampung Liman Benawi.

\section{METODE PENELITIAN}

Kegiatan pengabdian menggunakan metode pelatihan dalam melakukan transfer knowlegde kepada masyarakat. Pelatihan merupakan proses untuk memperbaiki keterampilan yang dimiliki seorang individu (Bangun, 2012, p.201). Proses pelatihan diawali dengan menjelaskan kepada petani terong manfaat dari inovasi produk. Setelah itu, petani terong dijelaskan tentang inovasi limbah terong untuk dijadikan keripik dan manisan terong. Pada akhirnya, produk olahan tersebut akan dibuatkan logo atau merek sebagai indetitas produk.

Pelaksanaan kegiatan pengabdian kepada masyarakat dilakukan di Kampung Liman Benawi, Kecamatan Trimurjo, Kabupaten Lampung Tengah, Provinsi Lampung. Masyarakat yang dilibatkan dalam kegiatan ini adalah para petani terong.
Dalam kegiatan pengabdian ini dilakukan oleh empat orang, yaitu: tiga orang memiliki keahlian dalam pengolahan makanan kreatif, dan satu orang yang memiliki keahlian dalam pemberian materi pelatihan dan konsultan merek.

\section{HASIL DAN PEMBAHASAN}

Dalam mengatasi masalah petani terong di Kampung Liman Benawi, pertama-tama kami melakukan pelatihan pembuatan produk kreatif, yaitu: manisan terong. Tahapan yang dilakukan, sebagai berikut:

a. Cuci buah terong sampai bersih.

b. Iris kulit semangka $2 \mathrm{~cm}$ melingkar.

c. Rendam irisan terong menggunakan kapur sirih selama 12 jam.

d. cuci rendaman tadi lalu rebus hingga lunak.

e. Masukan bahan-bahan, seperti gula pasir dan sitrun rebusan tadi.

f. Jika sudah meresap dan mengental, angkat lalu tiriskanlalu jemur di bawah terik matahari selama kurang lebih 2 hari setelah itu manisan siap dikemas.

Hasil dari pembuatan manisan terong, dapat dilihat pada gambar berikut:

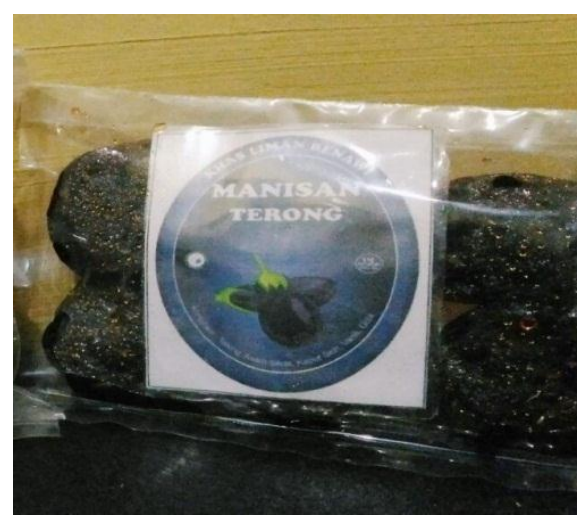

Gambar 1. Manisan Terong 
Selain manisan terong, produk olahan kreatif lain yang dibuat adalah keripik terong. Adapun bahan yang dapat digunakan untuk membuat keripik terong tersebut, yaitu : Terong, Baking soda, Bumbu dapur seperti, kemiri, garam, kunyit, ketumbar, daun jeruk dan bawang putih, minyak goreng, Mentega, dan Tepung beras.

Pada pelatihan yang dilakukan, dijelaskan tahapan dalam pembuatan keripik terong, sebagai berikut:

a. Cuci buah terong sampai bersih

b. Iris tipis-tipis terong yang sudah dicuci tadi

c. Cuci terong yang sudah direndang baking soda tadi campurkan bumbu yang sudah dihaluskan tadi dengan tepung beras sampai merata

d. Masukan irisan terong ke adonan tepung beras sedikit demi sedikit lalu goreng dengan minyak yang panas yang sudah dicampur dengan mentega

e. Jika sudah matang, angkat lalu tiriskan.

f. Setelah itu masukkan keripik terong kedalam ofen untuk menghilangkan kadar minyak dan membuat keripik semakin renyah.

g. Tambahkan bumbu balado untuk varian rasa dari keripik terong tersebut.

h. Setelah itu manisan siap dikemas

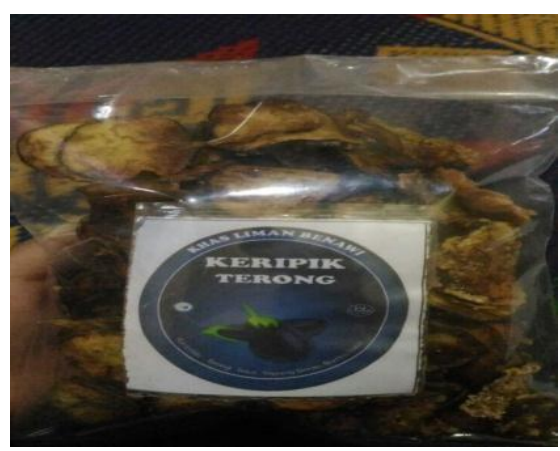

Gambar 2. Keripik Terong
Setelah produk olahan jadi, maka tahap selanjutnya adalah membuat branding, dengan membuat logo atau merek pada produk tersebut. Logo atau merek dalam kemasan, dapat dilihat sebagai berikut:

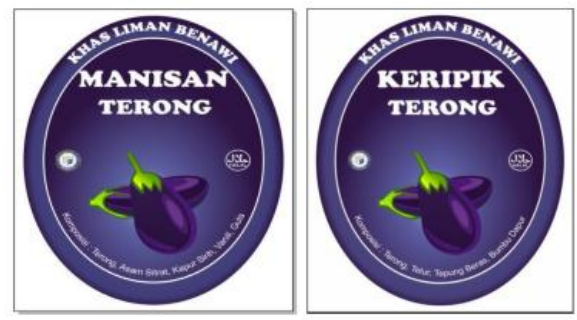

Gambar 3. Logo Produk
Setelah produk dan merek sudah jadi, langkah selanjutnya yang dilakukan adalah pemasaran produk. Saluran distribusi yang kami gunakan adalah media online, seperti: facebook, instagram, bukalapak.com, tokopedia.com, serta menggunakan web desa. Selain itu, kamu juga bekerjasama dengan inkubitek Insitut Informatika dan Bisnis Darmajaya, untuk memasarkan produk olahan ini dikalangan mahasiswa.

Dalam pembuatan produk olahan manisan terong dibutuhkan biaya operasional sebesar Rp. 10.500,00. Mempertimbangkan kondisi ekonomi calon konsumen, maka kami menjual produk sebanyak 3ons dengan laba yang diterima sebesar Rp. 4.500,00. Sehingga, dengan demikian harga jual yang kami tetapkan sebesar Rp. 15.000,00. Setelah melakukan observasi selama satu bulan, diproduksi 20 bungkus manisan terong, dan selama satu bulan, produk kami terjual habis. Sehingga keuntungan yang didapat sebesar Rp. $90.00,00$.

Produk lain yang diproduksi adalah keripik terong. Harga pokok produksi (HPP) dari keripik terong sebesar Rp. 13.500,00. Dengan begitu, produk ini dijual dengan harga $\mathrm{Rp}$. 
19.500, dengan laba bersih sebesar Rp.6.000,00. Setelah, dilakukan observasi selama satu bulan, keripik terong diproduksi sebanyak 10 bungkus dengan berat 5ons/bungkus. Dalam kurun waktu satu minggu, keripik terong sudah laku terjual, dengan keuntungan bersih sebesar Rp. $60.000,00$.

Melalui Observasi yang dilakukan, maka dapat diambil kesimpulan bahwa produk olahan kreatif membawa dampak positif bagi petani terong. Produk olahan kreatif, yang berupa manisan terong dan keripik terong memiliki nilai ekonomi yang jauh lebih tinggi dibandingkan dengan hasil panen terong yang tidak diolah. Oleh karena itu, sampai saat ini masih dilakukan produksi produk tersebut, terutama pada petani terong.

\section{KESIMPULAN}

Kesimpulan yang dapat diambil dari kegiatan pengabdian kepada masyarakat, sebagai berikut:

1. Produk olahan kreatif manisan terong, terbukti memiliki nilai jual yang lebih tinggi. Sehingga, implikasi kepada masyarakat, khususnya petani terong adalah mereka memperoleh pemasukan yang jauh lebih tinggi dibandingkan ketika menjual hasil panen mereka.

2. Produk olahan keripik terong, juga mendapatkan apresiasi dari masyarakat. Hal ini dibuktikan dengan, dalam kurun waktu satu minggu 10 bungkus produk tersebut sudah laku terjual. Sehingga, melalui produk ini, petani terong memiliki pendapatan yang lebih baik.

\section{UCAPAN TERIMAKASIH}

1. Kepala Desa Limah Benawi, Lampung Tengah, Lampung yang telah memberikan ijin dan memfasilitasi kegiatan pengabdian kepada masyarakat tersebut.

2. Petani Terong yang berada di Desa Limah Benawi yang telah bersedia meluangkan waktu, tenaga, dan pikiran sebagai peserta kegiatan pengabdian kepada masyarakat.

3. Lembaga Penelitian, Pengabdian, dan Pembelajaran (LP4M) Institut Informatika dan Bisnis yang telah memberikan dukungan berupa surat penghantar serta keuangan dalam memperlancar kegiatan tersebut.

4. Mahasiswa-Mahasiswa Jurusan Manajemen Insitut Informatika dan Bisnis Darmajaya yang tidak dapt disebutkan namanya satu-persatu, yang telah membantu tenaga, pikiran, dan waktu untuk mensuskseskan kegiatan tersebut.

\section{DAFTAR PUSTAKA}

1. Abdullah, Irwan, 2007 dalam Tukiran, et.al.2007, Sumber Daya Manusia Tantangan Masa Depan,Yogya-karta, Pusar Studi Kependudukan dan Kebijakan, Universitas Gadjah Mada.

2. Adi, Isbandi Rukminto, 2001, Pemberdayaan Pengembangan Masyarakat dan Intervensi Komunitas : Pengantar Pada Pemikiran dan Pendekatan Prakits,Jakarta : Lem- baga Penerbit Fakultas Ekonomi Universitas Indonesia

3. Bangun, Wilson. (2012). Manajemen Sumber Daya Manusia. Jakarta: Penerbit Erlangga

4. Chandar, Ilham., Hermawan Bambang. (2013). E-Commerce dan E-Business. Yogyakarta: Andi Offset.

5. Usaman, Sunyoto. (2003). Pembangunan Pemberdayaan Masyarakat. Yogkakarta: Pustaka Belajar. 